九州大学学術情報リポジトリ

Kyushu University Institutional Repository

\title{
A Middle Triassic Ammonite from the Isatomae Formation, Kitakami, Japan
}

Ishibashi, Takeshi

Faculty of Science, Kyushu University

https://doi.org/10.5109/1544205

出版情報：九州大學理學部紀要：Series D, Geology. 24（1)，pp.25-31，1978-11-10. Faculty of Science, Kyushu University バージョン:

権利関係: 
Mem. Fac. Sci., Kyushu Univ., Ser. D, Geol. Vol. XXIV, No. 1, pp. 25-31, text-figs. 1-7, pl. 7, November 10, 1978

\title{
A Middle Triassic Ammonite from the Isatomae Formation, Kitakami, Japan
}

\author{
Takeshi ISHIBASHI
}

\begin{abstract}
A Middle Triassic ammonite, Discoptychites inaicus (DIENER), is described based on a specimen from the Isatomae formation of the Kitakami Mountains, which is better preserved than the holotype. Notes are given on the ptychitid ammonites from Japan.
\end{abstract}

\section{Introduction}

As is well known, almost all of the Middle Triassic ammonites of Japan have been obtained from the Inai Group of the Kitakami Mountains. The present specimen was collected by the Late Mr. Akira ONO, a student of the Department of Geology, Kyushu University in 1944 from the type-locality of the Isatomae Formation with some indeterminable ammonites, and has been preserved at the Department of Geology, Kyushu University. The information about the locality and field evidence was given by Professor Emeritus Tatsuro Matsuмото of Kyushu University with whom A. ONo investigated the stratigraphy and geology of the Inai area at that time.

The stratigraphy and paleontology of the Triassic system distributed in the Kitakami Massif have been studied by many geologists. The Isatomae Formation (ONUKI and BANDo, 1959a) is the upper part of the Inai Group, and yields about 30 species of ammonoids. These ammonoids were described mainly by MoJsisovics (1888), Diener (1915), Shimizu (1930) and BANDo (1964). Two species of them, "Ptychites inaicus" and Ptychites sp., were described by DiENER (1915) from the rock quarry east of Isatomae, Miyagi Prefecture.

The present specimen was collected from another locality (Fig. 1). It is evidently identified to "Ptychites inaicus DIENER" but the generic name is changed to Discoptychites as mentioned below.

I express my sincere thanks to Professor Emeritus Tatsuro Matsumoto of Kyushu University who gave me useful information about the present material and valuable suggestions. Thanks are due to Professor Ryuzo ToRIYama of Fukuoka University for reading manuscript and encouragement.

\section{Notes on the ptychitid ammonites from Japan}

Considerably numerous ptychitid ammonites are known from the Middle 


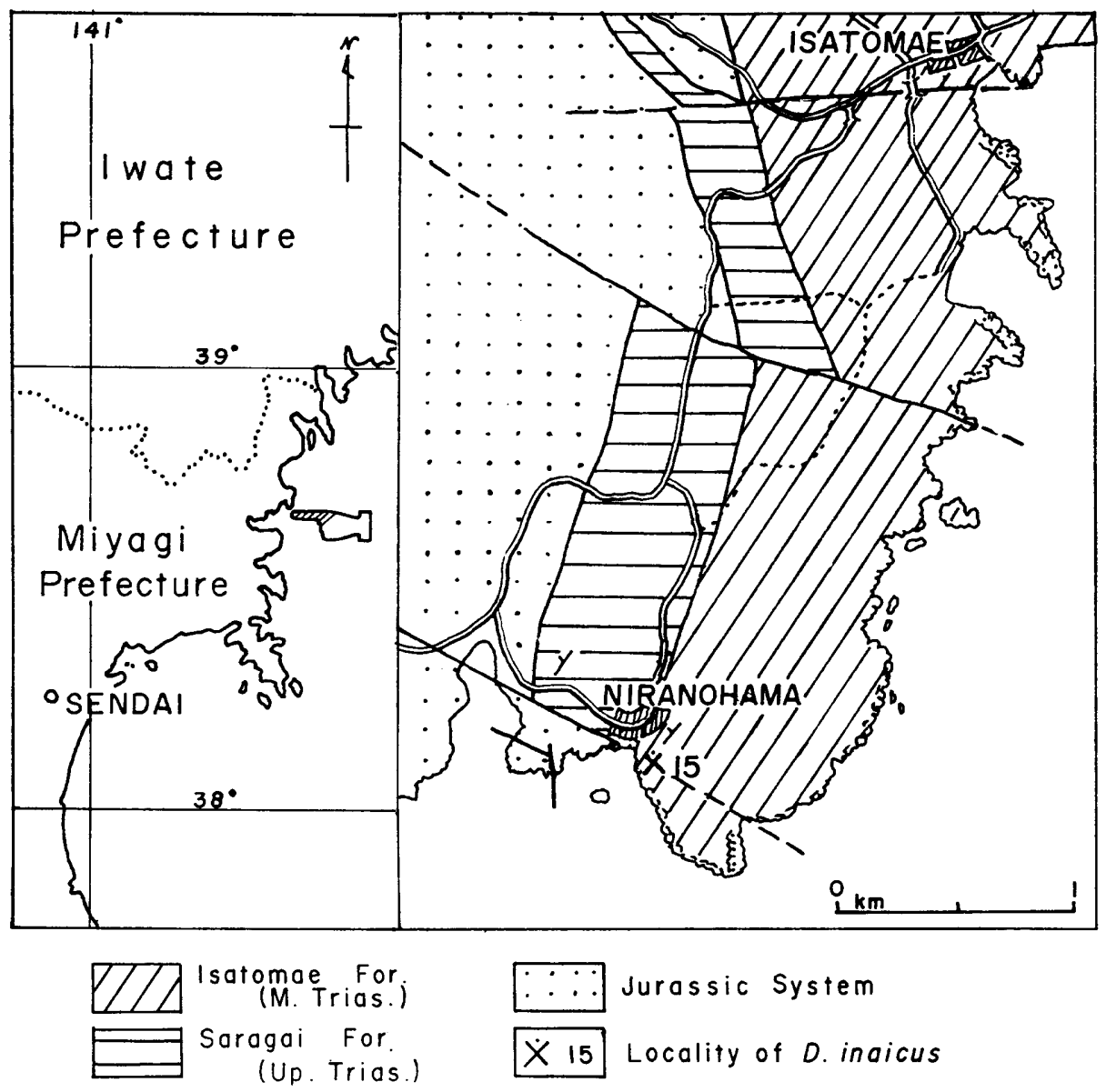

Fig. 1. Geological map simplified from the original of T. MAtSUmoto showing the locality of Discoptychites inaicus (DIENER)

Triassic of Japan. They are referred to the four genera, Ptychites, Flexoptychites, Discoptychites and Sturia, and occur in four formations as follows:

Isatomae Formation $\left\{\begin{array}{l}\text { Sturia japonica DIENER } \\ \text { [Kitakami] }\end{array}\left\{\begin{array}{l}\text { S. } \text { sansovinii (MoJsisonics) } \\ \text { S. } \quad \text { sp. } \\ \text { "Ptychites inaicus DIENER" } \\ \text { Ptychites sp. }\end{array}\right.\right.$

\section{Explanation of Plate 7}

Fig. 1. Discoptychites inaicus (DIENER) ......................... 29 Lateral view with whitening. See p.27, Fig. 3 and p. 30, Fig. 4-b. (GK. F567) 


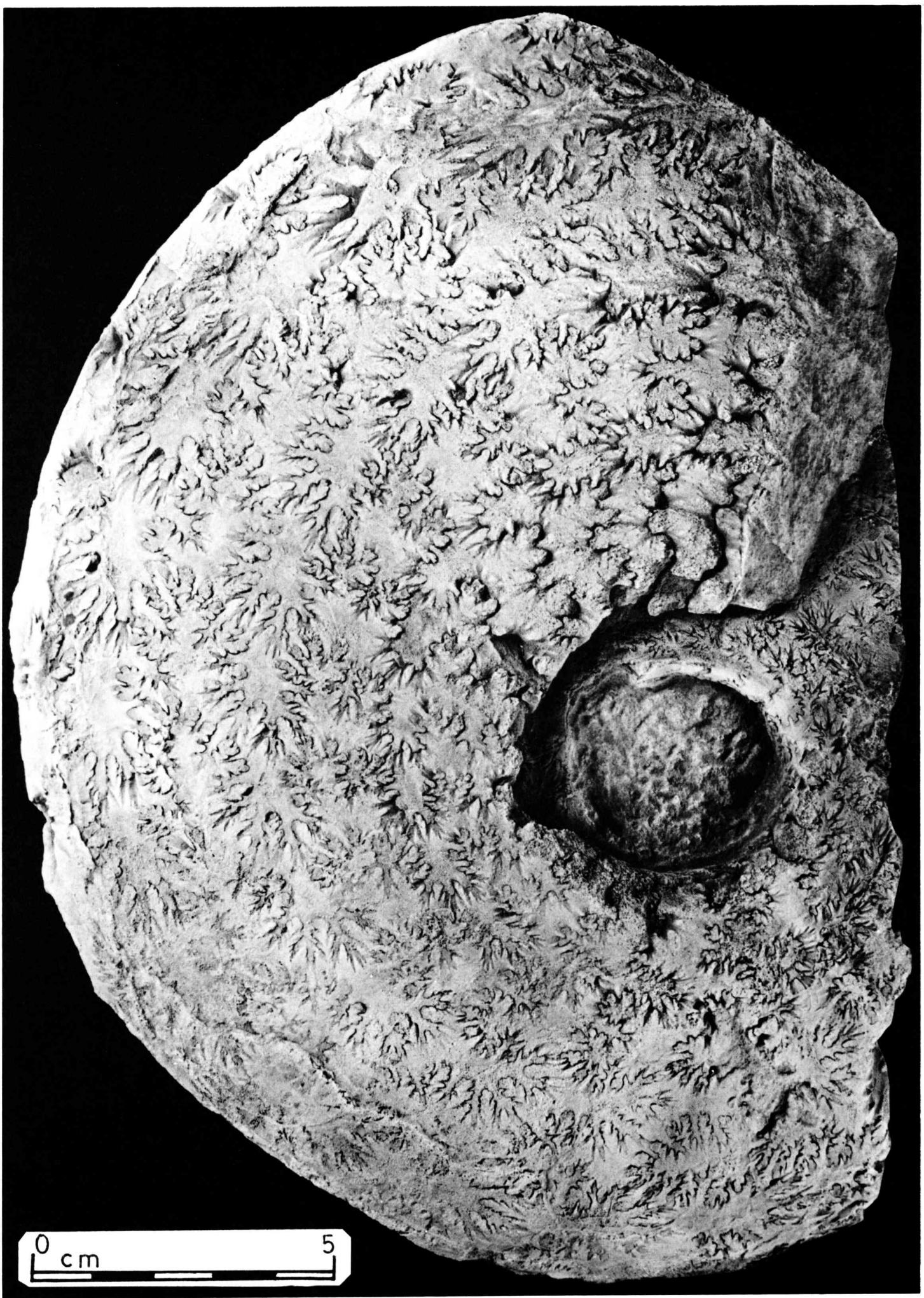

T. Ishibashi : Middle Triassic Ammonite 


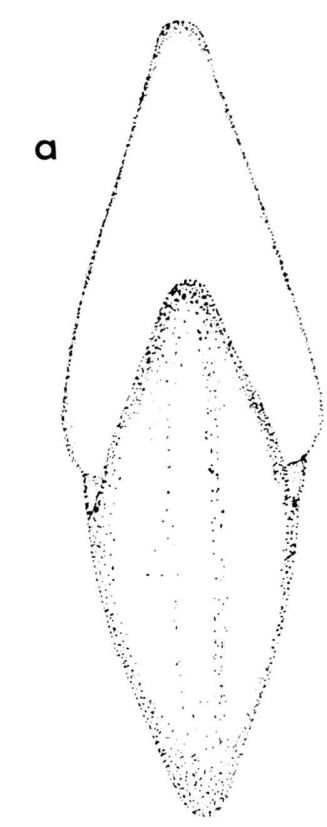

b

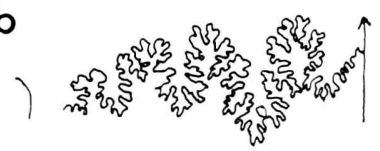

Fig. 2. Diagrammatic sketch of the type-species, Discoptychites megalodiscus (BEYRICH) a; frontal view $b$; suture-line $\times 1$

Fig. 3. Photograph of ventral view of Discoptychites inaicus. See Pl. 7, Fig. 1 and p. 30, Fig. 4-b.

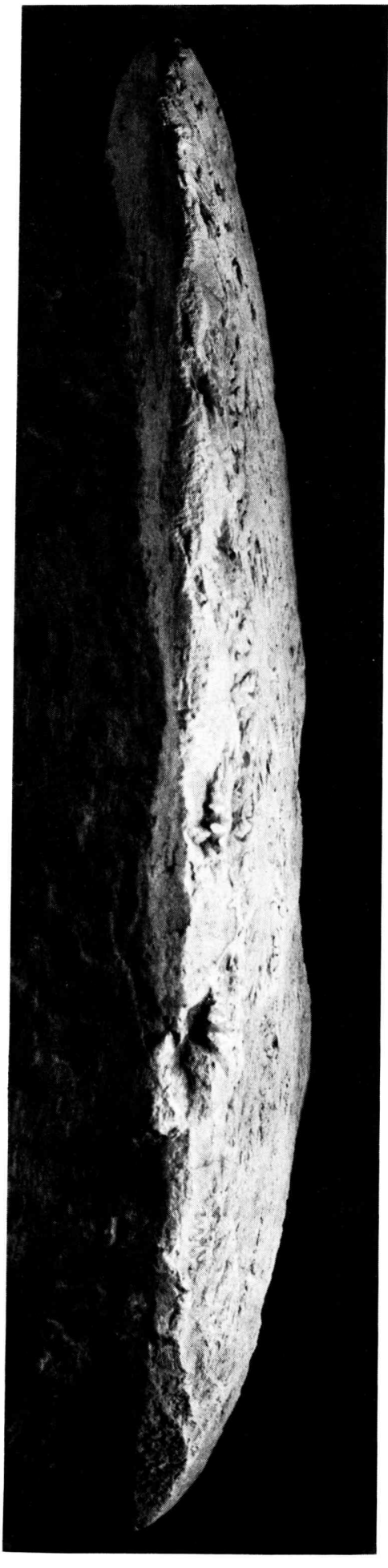


Rifu Formation [Kitakami]

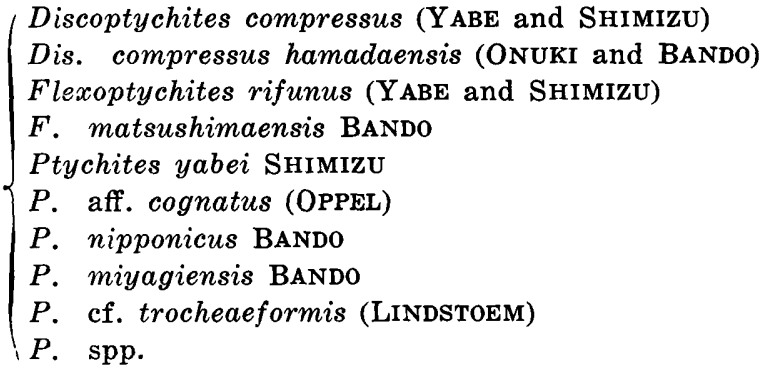

Ptychites sp.

Ptychites sp.

The Isatomae Formation (Upper Anisian) is characterized by the occurrence of Sturia. Sturia japonica DIENER is very similar in sculpture of lateral side and suture-line to Sturia sansovinii MoJsISovics reported by DIENER (1897) from the Himalaya region and to $S$. cf. sansovinii reported from the present formation (ONUKI and BANDO, 1959b). But $S$. japonica has a much larger shell $(550 \mathrm{~mm}$ in diameter), about two times as large as that of $S$. sansovinii from the Himalaya.

Two species of Discoptychites are now known from the Isatomae Formation and the Rifu Formation of the Inai Group. Discoptychites inaicus (DIENER) from the former is described in this article. Discoptychites compressus (YABE and Shimizu), originally described under the generic name of Ptychites, was transferred to Discoptychites by KIPARIsova (1961) and BANDo (1976). I rather agree with BANDO (1964, p. 61) to consider that Ptychites compressus could be rather referable to Flexoptychites than to Discoptychites, because Flexoptychites has distinct and wide radial ribs and complex suture-line: But as I have had no chance to examine the original material, I provisionally follow their current interpretation for the time being.

Flexoptychites rifunus (YABE and SHIMIZU) and F. matsushimaensis BANDo are known from the Rifu Formation and their stratigraphic position is referred to as the Ladinian in Japan. Some species of Ptychites are reported from the Ladinian Rifu and Zohoin Formations and the Anisian Tao Formation. Species of Ptychites from the latter two formations of Shikoku are indeterminable. The Rifu Formation yields a respectable number of specimens having sculptures on shells and suture line, but almost all of them are secondarily compressed laterally and their whorl sections are hardly seen with any precision. It follows that the precise generic assignment is difficult for some of the ptychytid ammonoids from Japan.

\section{Paleontology}

Family Ptychitidae MoJsisovics, 1882

Genus Discoptychites DIENER, 1916

Type-species:-Ammonite megalodiscus BEYRICH, 1867 
Remarks:-Based on Ptychites megalodiscus (BERYICH) as the type-species Discoptychites was established by DIENER (1916) for some Ptychites having an acute venter, but no generic diagnosis was given. However, it is strange that the genus Discoptychites was neglected by DIENER (1925) himself and KuTASSY (1933) in their systematics. Later this genus was revived by SPATH (1951) with establishment of Flexoptychites, Alloptychites, Metasturia, and Parasturia in the family Ptychitidae. He made clear the characteristics of the genus Discoptychites into which "Ptychites megalodiscus (BEYRICH)", "Ptychites evolvens MoJsisovics" and "P. fastigatus DiENER" were included. After SPATH this genus has been accepted by all paleontologists (i e., KUMMEL, 1957; 1960 : KIPARISOVA, 1961: BANDo, 1976; Venzo and Pelosio, 1968).

\section{Discoptychites inaicus (DIENER) \\ Pl. 7, Fig. 1: Fig. 3 and Fig. 4-b}

1915. Ptychites inaicus DIENER; Denkschr. Akad. Wiss. Wien, 92, p. 20, pl.4, figs. 1a-b.

Material.-The specimen at hand (GK.F 567) is $217 \mathrm{~mm}$ in diameter and about $18 \mathrm{~mm}$ in width, but it is laterally compressed secondarily. The umbilicus is about $40 \mathrm{~mm}$ in diameter. The living chamber is lost.

Description.-Shell large, involute discoidal, laterally compressed with acute venter. Side gently convex with very weak radial folding without spiral ribs, nodes or tubercles. Outer whorl deeply embracing almost all part of inner whorl, gradually increases its height, $103 \mathrm{~mm}$ high in the maximum. Umbilicus, rather narrow, $40 \mathrm{~mm}$ in diameter, its shoulder sharply rounded. Septa ammonitic, first lateral lobe deepest and second lateral lobe smaller with accessary lobes, lateral lobes near umbilical seam simple, second lateral saddle highest.

Remarks.-DIENER (1915) originally described Ptychites inaicus along with some bivalves and ammonoids which were deposited at Tohoku University or collected by himself. The holotype is evidently deformed to a egg-shape but low and wide ribs and suture-line are well preserved. The present specimen is not so much deformed as the holotype, and is easily referred to as "Ptychites inaicus" by the characteristics of shell and suture-line. In the original figure of the holotype the ventral view was not given by DIENER. The present specimen and the holotype resemble remarkably each other in the characters of sutures (Fig. 4). DIENER compared his specimen to Ptychites rugifer, the type-species of Ptychites, from the Muschelkalk of Europe, but Ptychites rugifer, including the holotype, from the Himalaya (DIENER, 1895, p. 64, pl. XXII, figs. 1-2, pl. XXIII, figs. 1-2, pl. XXIV, figs. 1-2) has globose shells like arcestid ammonites, distinct radial ribs and rounded ventrolateral shoulders.

The present species is closely related to Discoptychites megalodiscus, the type-species, described by BEYRICH (1867) from the Alps, in the shape of whorl section and the pattern of suture-line, but it is distinguished by the difference of width of umbilicus to diameter of whorl and suture-line (Fig. 2). The present specimen is rather similar to Discoptychites megalodiscus described by MoJsiso- 
a
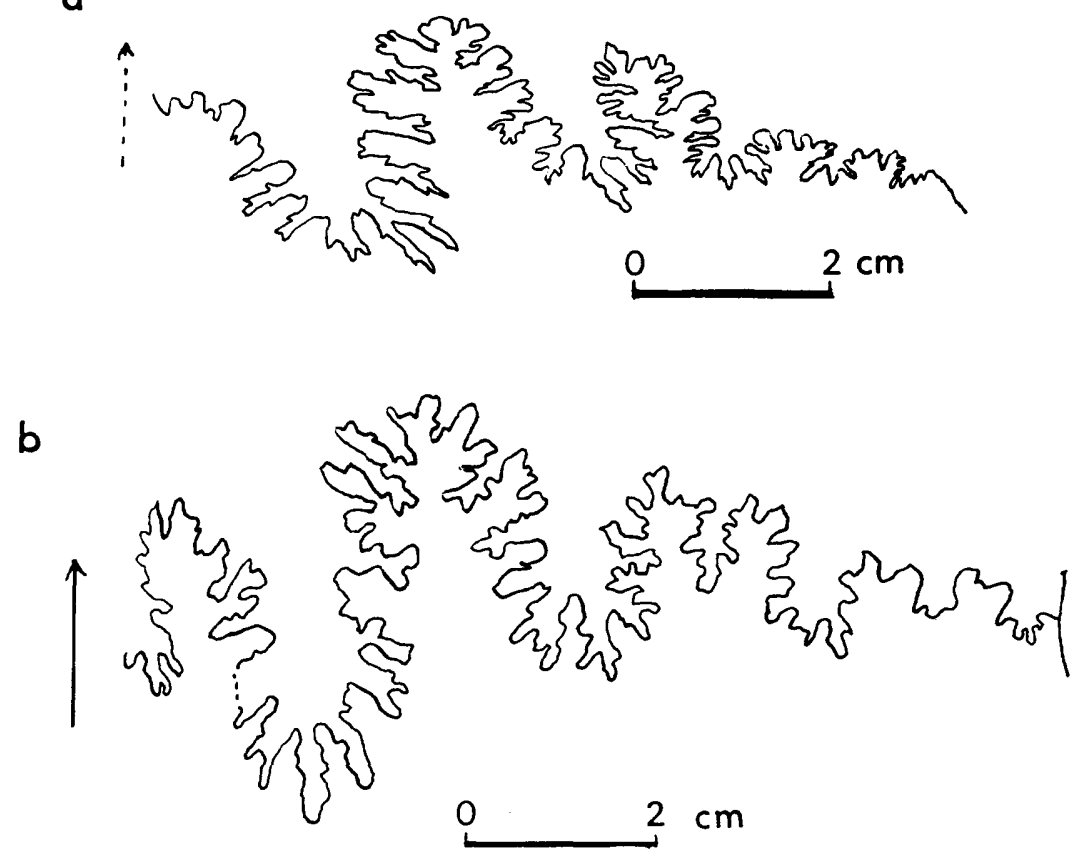

Fig. 4. Discoptychites inaicus (DIENER). Diagrammatic sketchs of suture-line of the holotype (a) and the present specimen (b) (at whorl-height $=100 \mathrm{~mm}$ )

VICS (1882, p. 253, pl. LXXVII, fig. 1, LXXVIII, figs. 1-2), having the shell size as large as the present specimen and very similar whorl section, but is slightly different in suture-line. In the latter the first lateral saddle is the highest, while in the former the second lateral saddle is the highest.

Discoptychites inaicus is considered to be most related to D. evolvens described by MoJsisovics (1882, p. 253, pl. LXXV, figs. 1 and 4, pl. LXXVI, fig. 1) from the Alps. One illustrated as pl. LXXV, fig. 1 has a shell as large as the present one, a similar whorl section, and similar pattern of suture-line. Other specimens referred to $D$. evolvens have been reported by several authors without illustration. Apart from them, a comparison is needed between the present specimen and the following two; one is D. cf. evolvens described by Venzo and Pelosio (1968, p. 126, pl.16, figs. 16a-c, 17a-c) from the northern area of Bergamo, Italy (the Bergamo Alps), the other was originally referred to Flexoptychites acutus (MoJsisovics) from the same mountains by CASATI and GNACCOLINI (1967, p.137, pl.10, figs. 7a,b), which is latter referred to $D$. evolvens by Venzo and Plesiso (1968, p. 127). These specimens are also similar to the present specimen but differ in having a smaller ratio of umbilicus to shell diameter and a wider rounded venter.

Occurrence.-Upper part of the Isatomae Formation (Anisian). Locality: 15, Southern coast of Niranohama, Utatsu-cho, Motoyoshi-gun, Miyagi Prefecture (Fig. 1). 


\section{References}

BANDo, Y. (1964) : The Triassic stratigraphy and ammonite fauna of Japan.. Sci. Rep. Tohoku Univ., 2nd (Geol.), 36, (1), 1-137, pls. 1-15.

(1976) : Lower and Middle Triassic ammonites from the southern part of Kitakami Massif 2. Atlas of Japanese Fossils, No.46-272 (Tr-11) (in Japanese).

BEYRICH, E. (1867) : Ueber einige Cephalopoden aus dem Muschelkalk der Alpen und Über verwandte Arten. Abhandl. Akad. Wiss. Berlin, 103-149, 5 pls.

Casati, P. and Graccolini, M. (1967): Geologia delle Alpi Orobie occidentali. Riv. Ital. Paleont. Strat., 73, (1), 25-162, 9 pls.

Diener, C. (1895): The Cephalopoda of the Muschelkalk. Palaeont. Indica, [15], 2, pt. 2, 1-120, pls. 1-31.

- (1915): Japanische Triasfaunen. Denkschr. Akad. Wiss. Wien, 92, 1-30, pls. $1-7$.

(1916) : Einige Bemerkungen zur Nomenklatur der Triascephalopoden. Zentralbl. Min. Geol. Paläont., 97-105.

(1925) : Leitfossilien der Trias. In Gürich, G., Leitfossilien 4, 1-118, pls. 1-28. Berlin.

KIPARISOVA, L. D. (1961): Paleontological basis of the stratigraphy of the Triassic Formation in Ussuriland pt 1 Cephalopoda. Trudy Boes, Nauts.-Issred., Geol. Inst., 48, 1-278, pls. 1-38.

Kummer, B. (1957): Cephalopoda, Ammonoidea in Treatise on Invertebrate Palaeontology, pt. L, Mollusca 4 (Ed. Moore, R. C.), 1-490, Geol. Soc. Amer. and Univ. Kansas Press.

(1960) : New Zealand Triassic Ammonoids. New Zealand Jour. Geol. Geophy., 3, (3), 486-509 incl. 3 pls.

KutAssy, A. (1933) : Cephalopoda Triadica II, Fossilium Catalogus, Animalia, Pars 56, 371-832, Junk, Berlin.

Mojsisovics, E. (1882): Die Cephalopoden der mediterranen Triasprovinz. Abhandl. Geol. Reichsanst. Wien, 10, 1-322, pls. 1-94. (1888) : Ubere einige japanische Triasfossilien. Beitr. Paläont. Geol. Oost.Ung., 7, 163-178, pls. 1-4.

ONUKI, Y. and BANDo, Y. (1959a): On the Inai Group of the Lower and Middle Triassic System. Tohoku Univ. Inst. Geol. Paleont. Contr., (50), 1-69. (in Japanese).

- and $(1959 \mathrm{~b})$ : On some Triassic ammonites from the Isatomae Formation. Japan. Jour. Geol. Geogr., 30, 97-103, pl. 8.

Shimizu, S. (1930): On some Anisic ammonites from the Hollandites Beds of the Kitakami Mountainland. Tohoku Imp. Univ., Sci. Rep. [2nd, Geol.], 14, (1), 6374, pl. 24.

Spath, L. T. (1951): The Ammonoidea of the Trias (II). Cat. Fossil Cephalopoda Brit. Mus. (Nat. Hist.), pt. 5, 228 p.

Venzo, S. and Pelosio, G. (1968): Nuova fauna a ammonoidi dell'anisico superiore di Lenna in val Brembana (Bergamo). Mem. Soc. It. Sc. Nat. e Museo St. Nat. Milano, 17, (II), 73-141, pls. 7-17. 